\title{
Share Pledging and Corporate Default Risk: Evidence from the Chinese Stock Market
}

\author{
Hongmei Xu \\ Department of Finance, International Business College, South China Normal University, Guangzhou, China
}

Email address:

hmxu@ibc.scnu.edu.cn

\section{To cite this article:}

Hongmei Xu. Share Pledging and Corporate Default Risk: Evidence from the Chinese Stock Market. Journal of Finance and Accounting. Vol. 9, No. 3, 2021, pp. 93-100. doi: 10.11648/j.jfa.20210903.15

Received: March 29, 2021; Accepted: May 17, 2021; Published: June 21, 2021

\begin{abstract}
In this paper, we assess the economic impact of share pledging by focusing on corporate debt default risk, the most disruptive events in the life of a corporation. Using Instrumental Variables and a regulatory change that increasing the possibility of share pledging as a quasi-exogenous shock, we establish that increased share pledging decreases corporate default risk. The baseline results are robust by eliminating the effect of financial crises, adding other control variables, constructing new PSM samples and use other proxies for default risk. Further tests show that the relation is attenuated in higher ownership concentration and lower ex-ante institutional ownership firms. Our results indicate that share pledging can be beneficial to shareholders and important stakeholders like creditors by reducing the likelihood of corporate default. Our paper throws additional light on the economic impact of share pledging. Although several studies argue that share pledging incentivizes corporate insiders to use corporate resources for private benefits and destroy firm value on the Taiwanese stock market, our findings indicate that share pledging facilitates external monitoring and enables creditors to protect themselves. Our overall findings are consistent with prior literature which shows that share pledging improves market value of Chinese A-share listed firms. We believe that as strong government intervention during market downturns may limit A-share listed firms' exposure to downside risk associated, share pledging can play a more positive role in our setting.
\end{abstract}

Keywords: Share Pledging, Default Risk, Ownership Concentration, Institutional Ownership

\section{Introduction}

Share pledging, the practice of shareholders use owned stocks as collaterals to secure loans from creditors, is pervasive around the world. ${ }^{1}$ However, government regulators are becoming increasingly worried about the potential costs of pledging shares. ${ }^{2}$ In this paper, we assess the economic impact of share pledging by focusing on default risk, the most disruptive events in the life of a corporation [4].

The relation between share pledging and corporate default risk is ex-ante ambiguous. When the stock price falls below a

\footnotetext{
1 For example, U.S. corporate insiders have pledged at least $\$ 15$ billion of their owned stocks to secure personal loans by the end of 2015 .

Source:

https://www.reuters.com/article/us-usa-executives-loans-idUSKCN0T61Y620151 117.

2 For example, in March 2018, a new rule on pledged-stock loans comes into effect in China, arguing that reckless borrowing by controlling shareholders destabilizes the market.
}

threshold, the borrower should pledge more shares or repay their loans; otherwise the creditor will liquidate the pledged shares, pushing the stock price down even further. ${ }^{3}$ Therefore, share pledging can expose firms to downside price pressures and increase default risk [7]. Alternatively, collateral can release additional information about the borrower and improve the creditor's incentive to monitor [19]. An increase in pledged shares can decrease default risk by facilitate external monitoring [4].

In this paper, we examine the effect of share pledging on default risk in China, where mandated disclosure of pledged shares and nontrivial collateral amounts enable us to tackle this empirical question. ${ }^{4}$ We employ identification strategies

\footnotetext{
3 For example, the liquidation of pledged shares contributes to a steep drop in Hong Kong's small-cap Growth Enterprise Market in late June 2017, when 17 stocks fall by more than 40 percent in a single day.

Source: https://www.ft.com/content/881bae58-e3c9-11e7-97e2-916d4fbac0da. 4 In China, the volume of pledged-stock loans reaches 1.28 trillion RMB (US\$ 188 billion) by the end of 2016. Source:
} 
including Instrumental Variable (IV) analysis and Differences-in-Differences (DiD) analysis, and observe a significant negative relation between share pledging and default risk.

Our paper throws additional light on the economic impact of share pledging. Although several studies argue that share pledging incentivizes corporate insiders to use corporate resources for private benefits and destroy firm value on the Taiwanese stock market [5, 7, 23], our findings indicate that share pledging facilitates external monitoring and enables creditors to protect themselves. Our overall findings are consistent with Li et al. [14] who show that share pledging improves market value of Chinese A-share listed firms. We believe that as strong government intervention during market downturns may limit A-share listed firms' exposure to downside risk associated, share pledging can play a more positive role in our setting. ${ }^{5}$

\section{Data Description and Summary Statistics}

\subsection{Sample Selection}

Our sample consists of A-share listed firms on Shanghai and Shenzhen stock exchanges during the period of 2003-2016. We collect data from the China Stock Market Trading Research database (CSMAR) provided by GuoTaiAn (GTA) Company include (1) annual financial statement, (2) monthly stock return data, and (3) the share pledging data. We exclude financial firms according to the classification standard of the China Securities Regulatory Commission (henceforth CSRC), and drop observations with missing values on main variables. To minimize the effect of outliers, we winsorize all continuous variables at the top and bottom $1 \%$. The sample selection process ends up with a maximum of 13,263 firm-year observations in our baseline regressions.

\subsection{Variable Measurements}

\subsubsection{Measures of Corporate Default Risk}

We construct the main dependent variable, $E D F$, by calculating the Naïve default probability measure of expected default frequency following Bharath and Shumway [3]. This measure has been used by prior studies focusing on default risk in the US $[11,6,9,22]$ and recent literature in China $[12$,

https://www.caixinglobal.com/2018-01-15/regulators-limit-pledged-stock-loans-1 01197973.html.

5 For example, it is reported that in November 2018, more than 500 billion yuan (US\$71.96 billion) in bailout funds have been proposed or established by local governments, brokerages and insurance firms to help Chinese private companies with liquidity issues or "share pledge" risks. In the meantime, China's insurers have answered the government's call to join the bailout of listed companies mired in the country's ongoing pledged-share crisis by planning to raise 68 billion yuan (US\$9.8 billion)

(https://www.asiatimes.com/2018/11/article/share-pledge-bailout-funds-now-exce ed-us71-96-bn/,

https://www.caixinglobal.com/2018-11-15/insurers-join-bailout-effort-as-pledgedshare-crisis-continues-101347637.html).
13, 15]. The Naïve model substitutes the distant-to-default measure from Merton [17] into a cumulative standard normal distribution to calculate the probability that the value of a firm's asset will be less than the face value of its debt. A higher $E D F$ indicates a higher likelihood of corporate default. Specifically, we calculate $E D F$ as follows:

$$
\begin{gathered}
D D_{i t}=\frac{\log \left(\frac{\text { Equity }_{i t}+\text { Debt }_{i t}}{\text { Debt }_{i t}}\right)+\left(r_{i t-1}-\frac{\sigma_{V i t}^{2}}{2}\right) \times T_{i t}}{\sigma_{V i t} \times \sqrt{T_{i t}}} \\
\sigma_{V i t}=\frac{\text { Equity }_{i t}}{\text { Equity }_{i t}+\text { Debt }_{i t}} \times \sigma_{E i t}+\frac{\text { Debt }_{i t}}{E q u i t y_{i t}+\text { Debt }_{i t}} \times\left(0.05+0.25 \times \sigma_{E i t}\right) \\
E D F_{i t}=\operatorname{Normal}\left(-D D_{i t}\right)
\end{gathered}
$$

where i donates listed firms and t donates year. In equation (1), we calculate the distant to default $(D D)$ according to Merton [17]. The variable Equity $_{i t}$ is the market value of equity calculated as the product of stock price and the number of shares outstanding; Debt $_{i t}$ is the face value of debt, which is calculated as the sum of current liabilities and one half of long-term debt; $r_{i t-1}$ is the lagged one year annual return, which is computed from the monthly stock return one year before; $\sigma_{E i t}$ is the stock volatility of calculated from the lagged one year monthly stock return; $\sigma_{V i t}$, is calculated from $\sigma_{E i t}$ in Equation (2), proxies the volatility of firm assets; and lastly, $T_{i t}$ is set to one year. The distant-to-default $\left(D D_{i t}\right)$ is constructed as of all sample firms as of the last day of each year. In Equation (3), Normal (.) is the cumulative standard normal distribution function. We substitute $D D_{i t}$ into this function to calculate $E D F_{i t}$.

\subsubsection{Measures of Share Pledging}

We then construct the main explanatory variable, Pledge. First, we measure share pledging as the amount of shares pledged by shareholders as a percentage of total shares outstanding at the end of the year.

Second, we also use a quasi-exogenous shock to share-pledging in 2013 to identify the real effect of share pledging. Thus, we construct an indicator variable Treat to donate firms that are largely affected by the shock. Specifically, following Brogaard et al. [4], we measure the change in Pledge from the pre-regulation year 2012 to the post-regulation year 2014, and construct a variable $\Delta$ Pledge -1 ${ }_{t o+1}$ for each firm. Based on $\Delta$ Pledge $_{-1}$ to +1 , we then sort the sample firms into deciles and regard the top three deciles of the distribution representing the firms experiencing the largest increase in share pledging. The dummy variable equals to one if firm $\mathrm{i}$ is included in the top three decile of $\Delta$ Pledge $e_{-1}$ to +1 and zero otherwise. We then construct a dummy variable Post to indicate the sub-period before and after the exogenous shock, Post equals to one if the year is after 2013 and zero otherwise.

\subsubsection{Control Variables}

Following Brogaard et al. [4], we include a vector of control variables as follows: Ln(Equity), the logarithm of market value of equity; $\operatorname{Ln}($ Debt $)$, the logarithm of face value of debt; 
$1 / \sigma_{E}$, the inverse of annualized stock return volatility; Excess return, the difference between annual stock return and market return; $R O A$, the ratio of net income to total asset. Table 1 provides details of definitions of all the variables in this paper.

Table 1. Variable definitions.

\begin{tabular}{|c|c|}
\hline Variables & Definitions \\
\hline$E D F$ & Expected default frequency, computed as N(-DD), where $\mathrm{N}($.$) is the cumulative standard normal distribution function.$ \\
\hline Pledge & The amount of shares pledged by shareholders as a percentage of total shares outstanding. \\
\hline Treat & A dummy variable equals to one if firm $i$ is included in the top three decile of Delta_Pledge, and zero otherwise. \\
\hline Post & A dummy variable that equals to one if the year is after year 2013, and zero otherwise. \\
\hline LnEquity & $\begin{array}{l}\text { The logarithm of market value of equity in year } \mathrm{t} \text {, the market value of equity is calculated as the product of the number of shares } \\
\text { outstanding and the stock price. }\end{array}$ \\
\hline LnDebt & The logarithm of the face value of debt in year $t$, calculated as the sum of debt in current liabilities and one-half of long-term debt. \\
\hline $1 / \sigma_{E}$ & $\begin{array}{l}\text { The inverse of annualized stock return volatility in year } \mathrm{t} \text {, the annualized stock return volatility is calculated as the standard deviation of } \\
\text { stock monthly returns over the prior year. }\end{array}$ \\
\hline$R O A$ & Return on asset, the ratio of net income to total asset in year t. \\
\hline ExcessRet & Annual excess return in year $\mathrm{t}$, calculated as the difference between firm stock return and the market return over the same period. \\
\hline
\end{tabular}

\subsection{Summary Statistics}

In this section, we report the summary statistics of the main variables. In Table 2, we find that the mean (median) of $E D F$ is $0.014(0)$, indicating the likelihood of default in Chinese firms is highly right skewed. Besides, the average $E D F$ in Chinese firms is relatively lower compared with the average EDF (0.062) of the US firms computed by Brogaard et al. [4]. This may due to the lower tolerant of defaults of the Chinese central and local governments. Therefore, government policies will help to prevent corporate defaults from escalating to a level that would cause systemic risk to the onshore and offshore markets.

We also document that the independent variable Pledge has a mean (median) of $0.157(0.123)$, indicating about $15.7 \%$ of the shares are pledged in the sample. Besides, the mean of the dummy variable Treat is 0.373 , which represents about $37 \%$ of the sample firms are largely affected by the exogenous shock of share pledging in 2013. The mean of Post is 0.156 , documenting about $15.6 \%$ of the observations are in the period after 2013. The other firm variables look relatively standard and also have a reasonable degree of variation, thus we do not describe these summary statistics in detail.

Table 2. Summary statistics (full sample).

\begin{tabular}{llllll}
\hline Variable & N & Mean & p50 & SD & Min \\
\hline EDF & 13263 & 0.014 & 0.000 & 0.082 & 0.000 \\
Pledge & 13263 & 0.157 & 0.123 & 0.153 & 0 \\
Treat & 13263 & 0.373 & 0 & 0.484 & 0 \\
Post & 13263 & 0.156 & 0 & 0.363 & 0.620 \\
LnEquity & 13263 & 22.133 & 22.132 & 1.069 & 1 \\
LnDebt & 13263 & 20.718 & 20.646 & 1.451 & 19.913 \\
1/ $\sigma_{E}$ & 13263 & 8.083 & 7.621 & 3.303 & 17.253 \\
ROA & 13263 & 0.024 & 0.027 & 0.070 & 1.767 \\
ExcessRet & 13263 & -0.003 & -0.004 & 0.021 & -0.319 \\
\hline
\end{tabular}

\section{Empirical Specification and Results}

\subsection{OLS Regression}

Before turning to causal interpretations, we examine the general relation between share pledging and corporate default risk. To assess how share pledging affects corporate default risk, we estimate the following model using ordinary least squares (OLS) estimation:

$$
\begin{aligned}
E D F_{i, t} & =\alpha+\beta_{1} \text { Pledge }_{i, t}+\beta_{2} \text { Control }_{i, t} \\
& + \text { Fixed Effects }+\varepsilon_{i, t}
\end{aligned}
$$

where $i$ indexes firm and $t$ indexes year. The coefficient on Pledge, $\beta_{1}$, is the one with main interest. Controls is a vector of control variables presented in Table 1. Besides, we control for both year- and firm-fixed effects to control for the time-variant heterogeneity and time-invariant unobserved heterogeneity at the firm level. Finally, we cluster standard errors at the firm level.

We report estimation results on the raw relation between share pledging and default risk in Column (1), Table 1. In Column (1), we find that the coefficient on Pledge is insignificant. The 2008-2009 financial crisis may boost firms' likelihood of default, which may result in an ambiguous estimation in Column (1). In Column (2), to eliminate the effect of the financial crises, we exclude observations during 
2006-2009. We obtain positive and significant coefficient on Pledge. In Column (3), we include other control variables, such as, the PPE ratio (PPE), firm size (LnAsset), the SA index $(S A)$, net profit (Profit), sales growth (Growth) and firm transparency (Transp) in to our specification. We still find a positive effect of share pledging on the likelihood of corporate default at the $5 \%$ level, indicating that higher share pledging is associated with lower default risk to some extent. Besides, the coefficients of all the control variables also have the expected signs as in Brogaard et al. [4].

It is noteworthy that the endogeneity concerns may bias our result because (1) the causality can run from the likelihood of default to the decision of pledging shares; (2) there are omitted variables correlated with both share pledging and default risk. Therefore, a naïve OLS regression may fail to capture the real effect of share pledging on default risk. To that end, we adopt two different identification strategies in the following sections.

Table 3. OLS regressions of share pledging on EDF.

\begin{tabular}{|c|c|c|c|}
\hline & (1) & (2) & (3) \\
\hline & Full sample & 2010-2016 & 2010-2016 \\
\hline \multirow[t]{2}{*}{ Pledge } & 0.0090 & $-0.0100^{*}$ & $-0.0104^{* *}$ \\
\hline & $(1.3461)$ & $(-1.9079)$ & $(-2.3591)$ \\
\hline \multirow[t]{2}{*}{ LnEquity } & $-0.0124^{* * *}$ & $-0.0064^{* * *}$ & $-0.0072^{* * *}$ \\
\hline & $(-5.4122)$ & $(-4.0739)$ & $(-4.8613)$ \\
\hline \multirow[t]{2}{*}{$\ln D e b t$} & $0.0118^{* * *}$ & $0.0109^{* * *}$ & 0.0016 \\
\hline & $(8.3255)$ & (10.1659) & $(1.3408)$ \\
\hline \multirow[t]{2}{*}{$1 / \sigma_{E}$} & $-0.0009^{* * *}$ & $-0.0007^{* *}$ & -0.0003 \\
\hline & $(-2.9831)$ & $(-2.3213)$ & $(-1.0464)$ \\
\hline \multirow[t]{2}{*}{$R O A$} & -0.0011 & $-0.0309^{* *}$ & $-0.0255^{*}$ \\
\hline & $(-0.0834)$ & $(-2.5266)$ & $(-1.7972)$ \\
\hline \multirow[t]{2}{*}{ ExcessRet } & -0.0089 & 0.0118 & 0.0162 \\
\hline & $(-0.2754)$ & $(0.3596)$ & $(0.5190)$ \\
\hline \multirow[t]{2}{*}{$P P E$} & & & 0.0062 \\
\hline & & & (1.2389) \\
\hline \multirow[t]{2}{*}{ InAsset } & & & 0.0032 \\
\hline & & & $(0.8004)$ \\
\hline \multirow[t]{2}{*}{$S A$} & & & $0.0069^{* *}$ \\
\hline & & & $(2.2657)$ \\
\hline \multirow[t]{2}{*}{ Profit } & & & $-0.0000^{* * *}$ \\
\hline & & & $(-4.0750)$ \\
\hline \multirow[t]{2}{*}{ Growth } & & & 0.0007 \\
\hline & & & $(0.7297)$ \\
\hline \multirow[t]{2}{*}{ Transp } & & & 0.0011 \\
\hline & & & $(0.9569)$ \\
\hline \multirow[t]{2}{*}{ _cons } & 0.0391 & $-0.1068^{* * *}$ & -0.0075 \\
\hline & $(0.9051)$ & $(-3.5482)$ & $(-0.1086)$ \\
\hline Year FE & $\mathrm{Y}$ & $\mathrm{Y}$ & $\mathrm{Y}$ \\
\hline Firm FE & $\mathrm{Y}$ & $\mathrm{Y}$ & $\mathrm{Y}$ \\
\hline$N$ & 10970 & 9035 & 5966 \\
\hline $\operatorname{adj} . R^{2}$ & 0.0538 & 0.0916 & 0.0976 \\
\hline
\end{tabular}

Notes: ${ }^{*} p<0.10,{ }^{* *} p<0.05,{ }^{* * *} p<0.01, t$ statistics in parentheses.

\subsection{An IV approach}

In this section, we first use the two-stage least squares (2SLS) approach to correct for the potential bias due to endogeneity in share pledging. We construct two instrument variables, Pledge_Ind, the average Pledge in the same CSRC 2-digit industry, and Pledge_Prov, the average Pledge in the same province, excluding firm i's own level of Pledge. The strategy of selecting IVs follows Faccio et al. [8]: These two IVs tend to isolate the more enduring and more exogenous component of share pledging by capturing the industry (provincial)-level factors explaining share pledging, while the decision of pledging shares of one firm does not influence the degree of share pledging of other firms.

Table 4 Column (1) reports the first-stage regression, shows that the two IVs perform reasonably well. In the second-stage regression reported in Column (4), the weak and over identification tests confirm that our IVs are statistically valid. The coefficient on Pledge is negative and significant, which implies that an increase in pledged shares reduces default risk. Regarding that the financial crisis may bias the estimated results, we further examine the causal in the sample period between 2010 and 2016. In Column (3), the coefficient on Pledge is still negative and significant, which confirms previous findings. ${ }^{6}$ Regarding that the heteroscedasticity concerns may bias our 2SLS regression, we also estimate a two-stage General Method of Moment (GMM) model to further examine the causal inference. In Column (4) and Column (5), we still find that share pledging has a significantly negative effect on the likelihood of default.

\subsection{DiD Analysis}

To further deal with potential endogeneity concerns, we rely on regulatory changes that generate plausibly exogenous variations in share pledging. Specifically, we follow Meng et al. [16] and explore a regulatory change in 2013 that permits security companies to lend money to borrowers using pledged shares as collaterals as a quasi-exogenous shock to share pledging. Before 2013, only banks and trust firms can participate in share-pledging activities. On May 24, 2013, the Shanghai Stock Exchange and the China Securities Depository and Clearing Co., Ltd. publish a rule ("The Guidance on Stock Pledge Repurchase Transactions, Registration, and Settlement") to guide the development of share pledging, permitting security companies to provide finance to borrowers based on pledge shares. As security companies require lower interest rates, have fewer restrictions on the usage of the loans, and approve transactions in a

\footnotetext{
6 Jiang (2017) indicates that the issue of IV estimates are larger than their corresponding OLS estimates is serious in finance studies, even if for papers published on leading journals. In our setting the ratio of $\left|\beta_{\text {iv }}\right|$ to $\left|\beta_{\text {ols }}\right|$ is about 23 $(=-0.2297 / 0.01)$. By comparison, this ratio is $15.48(=1.749 / 0.113)$ and 37.92 (=23.891/0.63) for Faccio et al. (2011) and Bernile (2018), two related studies using a similar strategy. Although coming up with a better cure for such problem is beyond this study, we follow Jiang (2017)'s advices to enhance the transparency of the effectiveness of the IV method and suggest audience to interpret the IV results with caution.
} 
quicker manner, this regulatory change encourages share pledging activities of listed firms.

Table 4. 2SLS Regressions of share pledging on default risk.

\begin{tabular}{llllll}
\hline & (1) First-stage & (2) Full sample 2SLS & (3) 2010-2016 2SLS & (4) Full sample GMM & (5) 2010-2016 GMM \\
\hline Pledge & & $-0.2297^{* *}$ & $-0.4400^{* *}$ & $-0.1992^{* *}$ & $-0.4066^{*}$ \\
& & $(-2.2955)$ & $(-2.0429)$ & $(-2.1505)$ & $(-1.8433)$ \\
Pledge_Ind & $0.0002^{* * *}$ & & & & \\
& $(4.2075)$ & & & & \\
Pledge_Prov & $0.0001^{* * *}$ & & & $Y$ & \\
& $(2.7089)$ & & $Y$ & 10.802 & 14.760 \\
Controls & $\mathrm{Y}$ & $\mathrm{Y}$ & 28.819 & 0.2550 & \\
Weak identification test & & 13.345 & 0.1691 & $\mathrm{Y}$ & \\
Hansen J Statistic & $\mathrm{Y}$ & $\mathrm{Y}$ & $\mathrm{Y}$ & $\mathrm{Y}$ & \\
Year FE & $\mathrm{Y}$ & $\mathrm{Y}$ & $\mathrm{Y}$ & 12902 & $\mathrm{Y}$ \\
Firm FE & 12902 & 12902 & 7889 & & 7889 \\
$\mathrm{~N}$ & & & & & \\
\hline
\end{tabular}

Notes: ${ }^{*} p<0.10,{ }^{* *} p<0.05,{ }^{* * *} p<0.01, t$ statistics in parentheses.

Table 5. PSM regression and post-match diagnostic regression.

Panel A

\begin{tabular}{lll}
\hline & Pre-match (1) & Post-match (2) \\
\hline LnEquity & 0.0291 & -0.0209 \\
& $(0.7861)$ & $(-0.4257)$ \\
LnDebt & $0.1234^{* * *}$ & -0.0104 \\
& $(5.5462)$ & $(-0.1905)$ \\
$1 / \sigma_{E}$ & .0009 & 0.0018 \\
& $(0.1102)$ & $(0.1806)$ \\
ROA & -0.0708 & -0.1320 \\
& $(-0.1604)$ & $(-0.2663)$ \\
ExcessRet & 0.6644 & -0.2188 \\
& $(0.5090)$ & $(-0.1521)$ \\
cons & $-2.4031^{* * *}$ & $-1.4019^{*}$ \\
& $(-3.6382)$ & $(-1.9285)$ \\
Ind FE & Yes & Yes \\
$N$ & 6768 & 6294 \\
$P$-value of Chi2 & 0.0000 & 0.0002 \\
Pseudo $R^{2}$ & 0.0073 & 0.0037 \\
\hline
\end{tabular}

Panel B

\begin{tabular}{llllll}
\hline $\begin{array}{l}\text { Propensity } \\
\text { scores }\end{array}$ & Min & P50 & Mean & SD & Max \\
\hline Treat & 0.5780 & 0.6978 & 0.6976 & 0.0435 & 0.8111 \\
Control & 0.5781 & 0.6918 & 0.6917 & 0.0432 & 0.8089 \\
Difference & -0.0001 & 0.0056 & 0.0059 & 0.0002 & 0.0022 \\
\hline
\end{tabular}

Panel C

\begin{tabular}{lllll}
\hline & Treat & Control & Difference & P-value \\
\hline LnEquity & 22.392 & 22.394 & -0.002 & 0.899 \\
LnDebt & 21.019 & 21.018 & 0.001 & 0.993 \\
$1 / \sigma E$ & 8.007 & 8.015 & $-0,008$ & 0.894 \\
ROA & 0.030 & 0.029 & 0.001 & 0.706 \\
Excessret & -0.002 & -0.002 & 0.000 & 0.718 \\
\hline
\end{tabular}

The empirical setting resembles Brogaard et al.[4] who employ decimalization as an exogenous shock and examine how stock market liquidity affects corporate default risk. We begin by constructing a treatment group and a control group of firms using propensity-score matching [18, 20]. Specifically, we measure the change in Pledge from the pre-regulation year 2012 to the post-regulation year 2014, and construct a variable $\Delta$ Pledge $e_{-1}$ to +1 for each firm. Based on $\Delta$ Pledge $_{-1 \text { to }+1}$, we then sort the sample firms into deciles and regard the top three deciles of the distribution representing the firms experiencing the largest increase in share pledging. When applying propensity score matching, we estimate a Probit model including all control variables from Equation (4) as well as industry-fixed effects. The dependent variable is equal to one if the firm-year belongs to the treatment deciles (top three deciles) and zero otherwise. We then use the estimated propensity scores to perform nearest-neighbor propensity score matching with replacement, with a propensity score match within 0.01 . In particular, each firm in the top three deciles (treatment firms) is matched to a firm from the rest deciles with the closest propensity score (control firms).

The validity of the DID estimator critically depends on the parallel trend assumption, i.e. the underlying trends in the outcome variable should the same for both groups. Following Brogaard et al. [4], we perform three diagnostic tests to verify that the assumption holds in our setting. We summarize the results of three-fold tests in Table $5 .{ }^{7}$

In Panel A, we re-run the Probit model used to estimate propensity scores restricted to the matched sample, and report estimation results in Column (2). Compared to the estimation results on the baseline Probit model in Column (1), the coefficients on all the explanatory variables have smaller magnitude and are not statistically significant, suggesting that there are no observable different characteristics exist between the treatment and control groups for the matched sample. Panel B reports the distribution of the propensity scores for both groups and their differences, and the difference between the propensity scores of the treatment firms and those of the control firms is trivial. In Panel $\mathrm{C}$, we report the univariate comparisons between the treatment and control firms' pre-regulation characteristics. As shown, none of the observed differences between the treatment and control firms' characteristics is statistically significant, suggesting the propensity score matching process removes meaningful observable differences. Therefore, it is more likely that the observed changes in corporate default risk (if any) are caused

\footnotetext{
7 We also following Brogaard et al. [4] exactly, and perform a nearest-neighbor propensity score matching without replacement. However, this method looses too many observations. Therefore, we made a trade-off between the two methods and choose to use the matching process with replacement. We also perform the regressions in the PSM sample without replacement and find similar basic results.
} 
only by the exogenous change in share pledging due to the regulation.

We construct the following DiD estimation:

$$
\begin{aligned}
E D F_{i, t}= & \alpha+\beta_{1} \text { Treat }_{i}+\beta_{2} \text { Post }_{i, t}+\beta_{3} \text { Treat }_{i} \times \text { Post }_{i, t}+ \\
& \beta_{4} \text { Control }_{i, t}+\text { Fixed Effects }+\varepsilon_{i, t}
\end{aligned}
$$

in Equation (5), $E D F_{i, t}$ and control variables are defined as in Equation (4). Treat $_{i}$ is a dummy variable that equals one if the stock i belongs to the treatment group, and zero otherwise. Post $_{i, t}$ is a dummy variable that equals to one if it is year 2013 or after, and zero otherwise. Our variable of interest is the coefficient on the interaction term of Treat $_{i}$ and Post ${ }_{i, t}, \beta_{3}$, which captures the change in default risk for treatment firms relative to benchmark firms subsequent to the regulatory change on share pledging. ${ }^{8}$ Lastly, in Equation (5), we also control the year- and firm-fixed effects to control for the time-variant heterogeneity and time-invariant unobserved heterogeneity at the firm level. We cluster standard errors at the firm level.

Then we conduct DiD analysis based on the matched sample. To begin with, we assess the validity of employing the deregulation of short-sales as quasi-exogenous shocks to share pledging. In Table 6 Column (1), we observe negative and significant coefficient on Treat $\times$ Post, indicating that the positive shock to share pledging reduces corporate default risk.

To observe the dynamics of corporate default around the time of the regulatory change, we conduct a timing test in Column (2). We introduce four indicator variables: Before 1, Current, After1, After 2+, which equals to one if it is one year prior to/the current year of/one year after/two and more years after/the regulatory change, and zero otherwise. We obtain insignificant coefficient on Treat $\times$ Before 1, implying that the pretreatment trends in share pledging are indistinguishable for the year prior to the events. By comparison, the negative and significant coefficients on Treat $\times$ Current, Treat $\times$ Afterl, and Treat $\times$ After $2+$ support that plausibly exogenous increases in share pledging due to the regulatory change lead to a significant decrease in corporate default risk.

\subsection{Robust Checks}

In this section, we make a series of robust checks to verify our DiD estimations. Table 7 reports the results. In Column (1), we delete observations of 2008-2009 to eliminate the effect of financial crisis. The result documents that the coefficient of Treat $\times$ Post is still negative and significant at the $5 \%$ level. In Column (2), we add other control variables that may also affect the likelihood of default in to our specifications. We still find that share pledging has a significantly negative effect on corporate default risk. In our main DiD specifications, based on $\Delta$ Pledge $e_{-1}$ to +1 , we sort the sample firms into deciles and regard the top three deciles of the distribution representing the firms experiencing the largest

8 As we control for year- and firm-fixed effects, variables Treat $t_{i}$ and Post $_{i, t}$ will be absorbed during the estimation. increase in share pledging. In this section, we use the median of $\Delta$ Pledge $e_{-1 \text { to }+1}$ to sort the sample and regard the top $50 \%$ of the distribution representing the firms experience larger increase in share pledging (treatment firms). Then we use the PSM strategy to find control firms for the treatment firms. Lastly, we estimate the DiD specification in this new PSM sample. Column (3) present the results, which indicates a significantly negative relation between share pledging and corporate default risk. In Column (4), we use other proxies for corporate default risk and re-estimate our DiD specification. Prior literature suggests that firms' distress risk is correlated with the likelihood of default. Firms face high default risk also have high distress risk, and vice versa [10, 21]. For example, Zhang et al. [24] found that Altman's Z-score variables accounted for about half of the estimated variation in default probabilities in Chinese firms [1]. Therefore, in Column (4), we use the Z-score as a proxy for corporate default risk and make DiD regression. Since higher Z-score represents lower distress risk, we find a significantly positive relation between share pledging and Z-score, indicating share pledging decreases firms' possibilities of distress. In sum, our robust checks confirm that share pledging reduces corporate default risk significantly.

Table 6. DiD analysis of the effect of pledge shares on default risk.

\begin{tabular}{lll}
\hline & EDF & EDF \\
\cline { 2 - 3 } & $\mathbf{( 1 )}$ & $\mathbf{( 2 )}$ \\
\hline Treat $\times$ Post & $-0.0092^{* *}$ & \\
Treat $\times$ Before1 & $(-1.9678)$ & \\
& & -0.0004 \\
Treat $\times$ Current & & $(-0.0550)$ \\
& & $-0.0108^{* *}$ \\
Treat $\times$ After1 & & $(-2.4061)$ \\
& & $-0.0089^{*}$ \\
Treat $\times$ After2 + & & $(-1.7775)$ \\
& & $-0.0081^{*}$ \\
Controls & $\mathrm{Y}$ & $(-1.7727)$ \\
cons & 0.0384 & $\mathrm{Y}$ \\
& $(0.6161)$ & 0.0371 \\
Year FE & $\mathrm{Y}$ & $(0.5995)$ \\
Firm FE & $\mathrm{Y}$ & $\mathrm{Y}$ \\
$N$ & 6294 & $\mathrm{Y}$ \\
adj. $R^{2}$ & 0.0595 & 6294 \\
\hline
\end{tabular}

Table 7. DiD Robust checks.

\begin{tabular}{lllll}
\hline & $\mathbf{( 1 )}$ & $\mathbf{( 2 )}$ & $\mathbf{( 3 )}$ & $\mathbf{( 4 )}$ \\
\cline { 2 - 5 } & EDF & EDF Add & EDF New & Z-score \\
& $\mathbf{2 0 1 0 - 2 0 1 6}$ & controls & PSM & \\
\hline Treat $\times$ Post & $-0.0104^{* *}$ & $-0.0093^{* *}$ & $-0.0076^{*}$ & $0.6226^{* *}$ \\
& $(-2.0499)$ & $(-2.0374)$ & $(-1.7926)$ & $(2.0391)$ \\
Controls & $\mathrm{Y}$ & $\mathrm{Y}$ & $\mathrm{Y}$ & $\mathrm{Y}$ \\
PPE & & $-0.0227^{* *}$ & & \\
& & $(-2.3310)$ & & \\
InAsset & & -0.0173 & & \\
& & $(-0.8247)$ & & \\
SA & & 0.0245 & & \\
Profit & & $(1.2500)$ & & \\
& & $-0.0000^{* * *}$ & & \\
Growth & & $(-3.1946)$ & & \\
& & 0.0027 & & \\
& & $(1.2874)$ & & \\
\hline
\end{tabular}




\begin{tabular}{lllll}
\hline & $(\mathbf{1})$ & $(\mathbf{2})$ & $\mathbf{( 3 )}$ & $\mathbf{( 4 )}$ \\
\cline { 2 - 5 } & EDF & EDF Add & EDF New & Z-score \\
\hline 2010-2016 & controls & PSM & \\
\hline _cons & -0.0240 & 0.4551 & 0.0259 & 15.0063 \\
& $(-0.3469)$ & $(1.2401)$ & $(0.4530)$ & $(1.0237)$ \\
Year FE & $\mathrm{Y}$ & $\mathrm{Y}$ & $\mathrm{Y}$ & $\mathrm{Y}$ \\
Firm FE & $\mathrm{Y}$ & $\mathrm{Y}$ & $\mathrm{Y}$ & $\mathrm{Y}$ \\
$N$ & 5168 & 6289 & 6745 & 6278 \\
adj. $R^{2}$ & 0.0458 & 0.0641 & 0.0570 & 0.6112 \\
\hline
\end{tabular}

\section{Cross-sectional Tests}

In this section, we examine whether the tendency of avoiding downward price pressures and the strength of external monitoring, measured by ownership concentration and institutional ownership respectively, can affect the relationship between share pledging and corporate default risk.

First, when controlling shareholders have larger stakes in the firm, they will have strong incentives to prevent margin calls [5]. In a margin call, if borrowers do not deposit more funds or repay the loan, the lenders could sell the pledged shares. When the amount of shares sold is high, controlling shareholders probably lose their control of the firm. Thus controlling shareholders would avoid margin call in a variety of ways. In our setting, we predict that controlling shareholders, especially when they have larger stakes in the firm, have stronger incentives to lower firms' likelihood of default to avoid margin call.

To test this assumption, we divide our sample into two subgroups with higher and lower ownership concentration with the sample median of ownership by the largest shareholder in each year. We estimate our DiD specification in the two sub-samples and report the results in Table 8 Column
(1) and Column (2). It is documented that the negative effect of share pledging is significant at the $5 \%$ level in the higher ownership concentration sample, however, the effect is not significant in the lower ownership concentration sample. The results indicate that controlling shareholders have great motivations to reduce corporate default risk to avoid downward price pressures from margin calls.

Second, creditors often require collateral in loan contracts to mitigate information asymmetry between the borrowers and lenders [2]. Therefore, collateral serves as an insurance to against firms' unfavorable conditions, such as default. Consequently, creditors will improve their incentives to monitor to insure their rights in the firm [19]. In our setting, the pledged shares also serve as collateral in loan contracts for firms, thus when management create a pledge on shareholdings for bank loans, the agency costs of outside investors can increase. In this situation, we predict that share pledging will facilitate creditors' external monitoring to the firm and decrease the likelihood of default, and the effect will be more pronounced in firms with ex-ante weaker external monitoring [4].

Institutional investors are active to the governance practice of listed firms, thus serve as an effective external monitoring mechanism. To examine the above prediction, we split the sample according to the sample median of institutional ownership in each year. Then we investigate the effect of share pledging on corporate default risk in each sub-sample. Table 8 Column (3) and Column (4) report the results. We find that the effect of decreased share pledging on default risk is more pronounced for firms with less ex-ante external monitoring (below-median institutional ownership), suggesting that share pledging enables creditors to monitor the share borrower and prevent default.

Table 8. Cross-sectional tests.

\begin{tabular}{lllll}
\hline \multirow{2}{*}{ Variables } & $(\mathbf{1})$ & $\mathbf{( 2 )}$ & $\mathbf{( 3 )}$ & $\mathbf{( 4 )}$ \\
\cline { 2 - 5 } & High Concentrate & Low Concentrate & High Instown & Low Instown \\
\hline Treat $\times$ Post & $-0.0164^{* *}$ & -0.0029 & -0.0058 & $-0.0227^{* *}$ \\
& $(-2.0583)$ & $(-0.5198)$ & $(-1.3183)$ & $(-2.2135)$ \\
Controls & $\mathrm{Y}$ & $\mathrm{Y}$ & $\mathrm{Y}$ & $\mathrm{Y}$ \\
Year FE & $\mathrm{Y}$ & $\mathrm{Y}$ & $\mathrm{Y}$ & $\mathrm{Y}$ \\
Firm FE & $\mathrm{Y}$ & $\mathrm{Y}$ & $\mathrm{Y}$ & $\mathrm{Y}$ \\
$N$ & 3147 & 3147 & 4415 & 2353 \\
adj. $R^{2}$ & 0.0681 & 0.0451 & 0.0449 & 0.0877 \\
\hline
\end{tabular}

\section{Conclusion}

In this paper, we examine the effect of share pledging on corporate default risk. We find that share pledging reduces default risk through an IV analysis and a DiD analysis. Our results are consistent in several of robust checks. For example, our baseline results are robust by eliminating the effect of financial crises, adding other control variables, constructing new PSM samples and use other proxies for default risk. The further examination shows that the effect of share pledging is more pronounced in firms with higher ownership concentration and lower ex-ante external monitoring. In general, our results indicate that share pledging can be beneficial to shareholders and important stakeholders like creditors by reducing the likelihood of corporate default.

Our paper throws additional light on the economic impact of share pledging. Although several studies argue that share pledging incentivizes corporate insiders to use corporate resources for private benefits and destroy firm value on the Taiwanese stock market, our findings indicate that share pledging facilitates external monitoring and enables creditors to protect themselves. Our results indicate that as strong government intervention during market downturns may limit A-share listed firms' exposure to downside risk associated, share pledging can play a more positive role in our setting. 


\section{References}

[1] Altman E I. Financial ratios, discriminant analysis and the prediction of corporate bankruptcy [J]. Journal of Finance, 1968, 23 (4): 589-609.

[2] Berger A N, Udell, G F. Collateral loan quality and bank risk [J]. Journal of Monetary Economics, 1990, 25 (1): 21-42.

[3] Bharath S, Shumway T. Forecasting default with the Merton distance to default model [J]. Review of Financial Studies, 2008, 21 (3): 1339-1369.

[4] Brogaard J, Li D, Xia Y. Stock liquidity and default risk [J]. Journal of Financial Economics, 2017, 124 (3): 486-502.

[5] Chan K, Chen H, Hu S, et al. Share pledges and margin call pressure [J]. Journal of Corporate Finance, 2018, 52: 96-117.

[6] Chava S, Purnanandam A. Is default risk negatively related to stock returns? [J]. Review of Financial Studies, 2010, 23 (6): 2523-2559.

[7] Dou Y, Masulis R W, Zein J. Shareholder wealth consequences of insider pledging of company stock as collateral for personal loans [J]. Review of Financial Studies, 2019, forthcoming.

[8] Faccio M, Marchica M, Mura R. Large shareholder diversification and corporate risk-taking [J]. Review of Financial Studies, 2011, 24 (11): 3601-3641.

[9] Garlappi L, Shu T, Yan H. Default risk, shareholder advantage, and stock returns $[\mathrm{J}]$. Review of Financial Studies, 2006, 21 (6): 2743-2778.

[10] Guedhami O, and Pittman J. The importance of IRS monitoring to debt pricing in private firms [J]. Journal of Financial Economics, 2008, 90 (1): 38-58.

[11] Hovakimian A, Kayhan A, Titman S. Are corporate default probabilities consistent with the static trade-off theory? [J]. Review of Financial Studies, 2012, 25 (2): 315-340.

[12] Huang Y, Miao J, Wang P. Saving china's stock market [J]. 2016, working paper.
[13] Law D, Roache S K. Assessing default risks for Chinese firms: A lost cause? [M]. International Monetary Fund, 2015.

[14] Li M, Liu C, Scott T. Share pledges and firm value. Pacific-Basin Finance Journal, 2019, forthcoming.

[15] Liu L, Luo D, Han L. Default risk, state ownership and the cross-section of stock returns: evidence from China [J]. Review of Quantitative Finance and Accounting, 2018: 1-34.

[16] Meng Q, Ni X, Zhang J. Share pledging and corporate risk-taking: Insights from the Chinese stock market [J]. 2019, working paper.

[17] Merton R. On the pricing of corporate debt: The risk structure of interest rates [J]. Journal of Finance, 1974, 29 (2): 449-470.

[18] Ni X, Zhu W. Short-sales and stock price crash risk: Evidence from an emerging market $[\mathrm{J}]$. Economics Letters, 2016, 144: $22-24$.

[19] Rajan R, Winton A. Covenants and collateral as incentives to monitor [J]. Journal of Finance, 1995, 50 (4): 1113-1146.

[20] Rosenbaum P, Rubin D. The central role of the propensity score in observational studies for causal effects [J]. Biometrika, 1983 70 (1): 41-55.

[21] Serfling M. Firing costs and capital structure decisions [J]. The Journal of Finance, 2016, 71 (5): 2239-2286.

[22] Vassalou M, Xing Y. Default risk in equity returns [J]. Journal of Finance, 2004, 59 (2): 831-868.

[23] Wang Y, Chou R. The impact of share pledging regulations on stock trading and firm valuation [J]. Journal of Banking \& Finance, 2018, 89: 1-13.

[24] Zhang, W., G. Han, and S. Chan. How Strong are the Linkages between Real Estate and Other Sectors in China? [J] HKIMR Working Paper, 2014, 11.

\section{Biography}

Hongmei Xu, corresponding author, an Associate Professor of Finance, in the International Business College, South China Normal University. 